\title{
Adoptive T Regulatory Cell Therapy for Tolerance Induction
}

\author{
Cecilia Cabello-Kindelan $^{2} \cdot$ Shane $_{\text {Mackey }^{2}} \cdot$ Allison L. Bayer $^{1,2}$
}

Published online: 2 April 2015

(C) Springer International Publishing AG 2015

\begin{abstract}
There is a clear need to develop strategies to induce tolerance without the need of chronic immunosuppression in transplant recipient and in patients with autoimmunity. Adoptive $T$ regulatory cell $\left(\mathrm{T}_{\text {reg }}\right)$ therapy offers the potential of long-lasting protection. However, based on results of clinical trials so far with ex vivo expanded autologous $T_{\text {regs }}$ in type 1 diabetic (T1D) patients, it seems unlikely that single immunotherapy with $\mathrm{T}_{\text {reg }}$ infusion without immunomodulation regimens that promote stable donor $T_{\text {reg }}$ engraftment and persistence would afford truly significant clinical benefit. Combination therapies could provide improved outcomes with consideration of the fundamental factors required for $\mathrm{T}_{\text {reg }}$ generation, homeostasis, and function to promote long-term donor $\mathrm{T}_{\text {reg }}$ persistence to provoke beneficial therapeutic outcomes.
\end{abstract}

Keywords T cells $\cdot$ T regulatory cells $\cdot \mathrm{IL}-2 \cdot$ Tolerance $\cdot$ Transplantation

$\begin{array}{ll}\text { Abbreviations } \\ \text { APC } & \text { Antigen presenting cell } \\ \text { BM } & \text { Bone marrow } \\ \text { DC } & \text { Dendritic cell } \\ \text { GVHD } & \text { Graft versus host disease }\end{array}$

This article is part of the Topical Collection on Cellular Transplants

Allison L. Bayer

abayer@med.miami.edu

1 Department of Microbiology and Immunology, Miller School of Medicine University of Miami, 1450 NW 10th Avenue, Miami, FL 33136, USA

2 Diabetes Research Institute, University of Miami Miller School of Medicine, Miami, FL 33136, USA
NK
Natural killer cell
$\mathrm{T}_{\text {eff }}$
$T_{\text {regs }}$
$\mathrm{T}$ effector cell
$\mathrm{T}$ regulatory cells
T1D
Type 1 diabetes

\section{Introduction}

Solid organ transplantation is a well-established treatment for patients with end-stage organ failure. Advances in surgical techniques and development of immunosuppressive drugs targeted at T-cell responses responsible for graft destruction have been key in improving short-term outcomes. However, there still remains the risk of chronic rejection and in the case of pancreatic or islet transplantation for T1D patients, therapeutic success is curtailed by recurrence of autoimmunity, despite immunosuppression that prevents rejection [1-6]. Moreover, chronic immunosuppression has significant toxicity and is associated with serious side effects, including increased susceptibility to infections. Therefore, there is a clear need to develop strategies for clinically applicable therapeutic protocols which are aimed at promoting tolerance induction that minimizes or eliminates long-term immunosuppression.

Immune tolerance is a state of unresponsiveness in the immune system. Self or natural tolerance is failure to attack the body's own proteins or other antigens. If the immune system attacks its own cells or tissues, an autoimmune disease could develop. Induced tolerance is lack of an immune response to external antigens that has been generated purposefully by modulating the immune system. This type of tolerance is important in cases of transplantation where the patients' immune cells "see" the allograft as foreign and mount an aggressive attack against it leading to graft rejection. Therapies in transplant setting are designed to target innate and/or adaptive immune responses that are thought to contribute to 
graft rejection. Another approach to immunotherapy would involve promoting tolerance mechanisms through enhanced regulation of adaptive T-cell responses. Central T-cell tolerance occurs in thymus where $\mathrm{T}$ cells develop and mature through a process of T-cell receptor (TCR) recognition of "self" antigens nestled in a major histocompatibility complex. Since high-affinity interaction could attack cells that display these self-peptides derived from body proteins, these $\mathrm{T}$ cells are eliminated through negative selection. Surviving thymic $T$ cells leave and migrate throughout peripheral immune system (Fig. 1).

A central issue of modern medicine is how peripheral selftolerance is achieved and preserved as increasing evidence has clearly demonstrated that potentially self-destructive T-cell clones can escape central tolerance and circulate in periphery of healthy individuals. There are several mechanisms for achieving peripheral tolerance, including anergy, negative selection occurring in the periphery, and control by regulatory $\mathrm{T}$ cells $\left(T_{\text {regs }}\right)$ (Fig. 1). In this review, we will summarize the $T_{\text {reg }}$ population and their use as adoptive T-cell therapy for tolerance induction strategies. This review will also focus on thymus-derived, natural $\mathrm{T}_{\text {regs }}$ rather than induced regulatory $\mathrm{T}$ cells that are generated with TCR engagement and cytokines, since studies are demonstrating that natural $\mathrm{T}_{\text {regs }}$ are more stable population and potent suppressors of "self" and in preventing autoimmunity [7-9]. $\mathrm{T}_{\text {reg }}$-based immunotherapy could significantly impact development of new therapeutic protocols for transplant recipients and patients with autoimmunity based on administration of a T-cell population that could afford long-lasting protection from rejection and autoimmunity without the need for chronic immunosuppression. The first clinical trials with adoptive $T_{\text {reg }}$ therapy has occurred in graft-versus-host-disease (GVHD) prevention trials in bone marrow (BM) transplant recipients with promising results [10, 11]. However, $T_{\text {reg }}$ therapy could show promise in patients with autoimmunity, such as T1D, but pose more challenges due to the underlying autoimmune responses as well as in the context of allogeneic islet or pancreatic transplantation in these patients.

Fig. 1 T-cell tolerance mechanisms. Central tolerance occurs in the thymus when highaffinity self-reactive $T$ cells are eliminated. Low-affinity selfreactive $T$ cells escape negative selection and migrate to the periphery, where they are controlled by several mechanisms, including regulatory $\mathrm{T}$ cells

\section{Adoptive T Regulatory Cell Therapy for Tolerance Induction}

Adoptive immunity was first described by Billingham et al., in which studies showed transfer of primed immune cells could generate or "pass" immunity in recipient mice [12]. Since this time, several animal studies have shown that T-cell adoptive transfer of immunity in settings of cancer, infection, and transplantation [13-16]. T-cell adoptive therapy was then further extended in application by the use of IL-2 for ex vivo expansion of human T cells [17-20]. The idea of suppressor $T$ cells was first suggested by two rodent studies from Gershon and Kondo $[21,22]$ that demonstrated the role of thymic lymphocytes in tolerance induction. A seminal study by Hall et al. demonstrated that $\mathrm{CD} 4 \mathrm{~T}$ cells, specifically $\mathrm{CD} 4^{+} \mathrm{CD} 25^{+}$cells, were capable of mediating transplantation tolerance $[23 \bullet \bullet]$. Furthermore, Sakaguchi's group identified a crucial subset of $\mathrm{CD}^{+} \mathrm{T}$ cells that expressed the IL-2R $\alpha$-chain (CD25) that functions in controlling peripheral tolerance and the development of autoimmune disease in mice and that $\mathrm{CD} 4^{+} \mathrm{CD} 25^{+} \mathrm{T}$ cells from naive mice could prevent rejection of allogeneic skin grafts in nude mice receiving $\mathrm{CD}^{+} \mathrm{CD} 25^{-}$T cells [24•]. Since this time, there has been extensive study of $\mathrm{CD} 4{ }^{+} \mathrm{CD} 25^{+} \mathrm{T}_{\text {regs }}$, which has further shown these cells are present in humans and function in all aspects of immune regulation $[25,26]$.

$\mathrm{CD} 4^{+} \mathrm{CD} 25^{+} \mathrm{T}_{\text {regs }}$ naturally develop in thymus as a fully functional distinct $\mathrm{CD} 4^{+} \mathrm{T}$-cell subset that migrates to periphery to actively suppress auto-reactive $\mathrm{T}$ cells that escape thymic negative selection. These $\mathrm{CD} 4{ }^{+} \mathrm{CD} 25^{+} \mathrm{T}_{\text {regs }}$ were later found to uniquely express the transcription factor Foxp3 [27-29] allowing more precise examination of their basic biology. Mutations or absence of Foxp3 leads to immune compartments devoid of $\mathrm{CD} 4^{+} \mathrm{CD} 25^{+} \mathrm{T}_{\text {regs }}$ and mice die within 1 month of birth. The identification of mutations in Foxp3 gene in scurfy mice and in Immune dysregulation, Polyendocrinopathy, Enteropathy, X-linked (IPEX) syndrome in humans, both of which succumb to lethal autoimmune disease early in life, was critical in establishing an essential role of $T_{\text {regs }}$ in the maintenance of peripheral self-tolerance. In mice, Foxp3 reduction

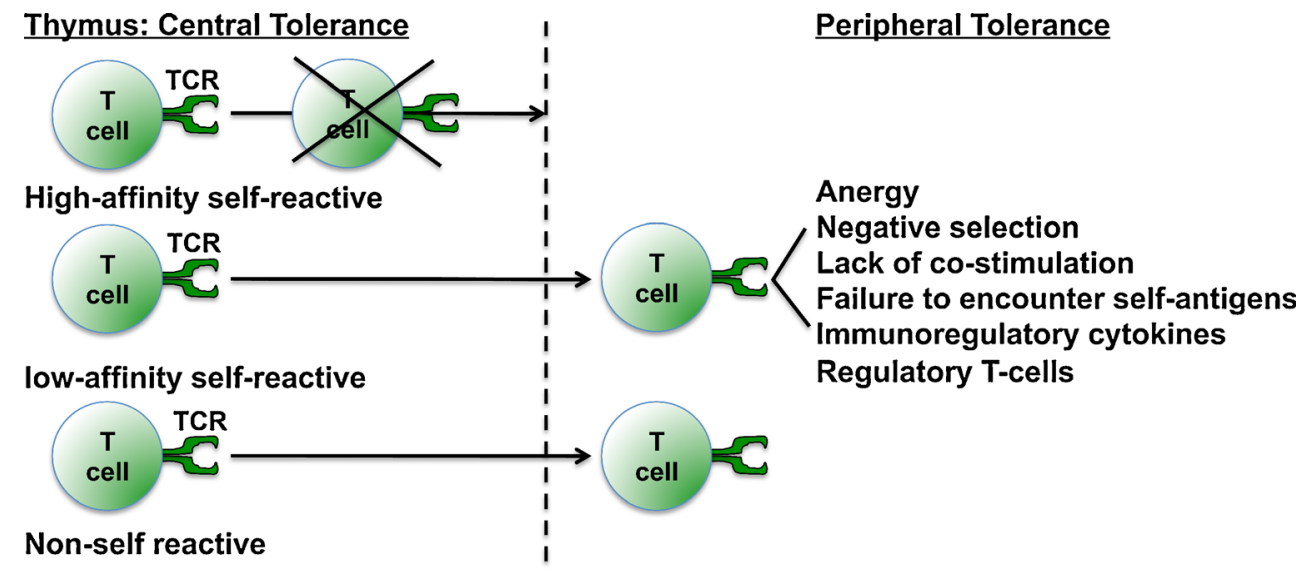


or functional alterations results in spontaneous development of various organ-specific autoimmune diseases, including gastritis, thyroiditis, and diabetes $[24 \bullet, 30,31]$. Adoptive transfer of $\mathrm{CD}^{+} \mathrm{CD} 25^{+} \mathrm{T}_{\text {regs }}$ into Foxp3-deficient mice rescues disease development [27]. Importantly, these results following ablation demonstrated that natural $\mathrm{T}_{\text {regs }}$ are the dominant mechanism controlling self-tolerance and insufficiency of other mechanisms of peripheral tolerance in these mice.

$\mathrm{T}_{\text {reg-dependent alloantigen tolerance has been induced in a }}$ variety of both in vitro and in vivo experimental models with active regulation critical for both inducing and maintaining immunological unresponsiveness to donor alloantigens [32-34]. Tolerance induction protocols in transplant setting

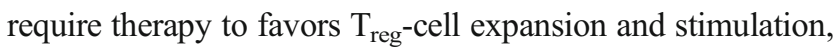
while inhibiting alloreactive effector responses [32-39], thereby tipping balance towards regulation. Moreover, $\mathrm{T}_{\text {regs }}$ have not only been detected in recipient's lymphoid tissues but also within the graft site [36]. The fact that $T_{\text {regs }}$ can be found in multiple locations is probably critical for effective inhibition of an aggressive attack towards transplanted tissue. Furthermore, adoptive transfer of fully allogeneic $\mathrm{T}_{\text {regs }}$ into neonatal IL-2R $\beta^{-/-}$mice prevents lethal autoimmunity associated with IL-2/IL-2R deficiency, but also confers tolerance to skin grafts bearing the $\mathrm{MHC}$ of donor $\mathrm{T}_{\text {regs }}[40]$. Others have shown that donor or host ex vivo expanded $\mathrm{T}_{\text {regs }}$ together with allogeneic BM cells prevents GVHD and facilitates BM engraftment [41-43], but these studies did not examine persistence of donor $\mathrm{T}_{\text {regs }}$ or requirements for stable donor $\mathrm{T}_{\text {reg }}$ engraftment. In the setting of allogeneic BM transplantation, substantial donor $\mathrm{T}_{\text {reg }}$ engraftment initially may be sufficient to allow mixed chimerism to occur and reset immune system through central tolerance. However, in context of organ transplantation or autoimmunity, it may be necessary to maintain a population of donor $\mathrm{T}_{\text {regs }}$, even perhaps antigen-specific $\mathrm{T}_{\text {regs }}$, long term in order to establish and maintain a tolerant state.

Given the essential role $T_{\text {regs }}$ play in self-tolerance [24•, 44, 45] and these cells suppress rejection of various allografts makes these cells highly attractive candidates for cell-based therapy for tolerance induction protocols in transplantation and autoimmune settings. Collectively, these experimental models suggest that $T_{\text {regs }}$ might be used in non-toxic approaches for preventing GVHD, allograft rejection, and restoring self-tolerance. However, the clinical application of adoptive $T_{\text {reg }}$ therapy is hindered by low $T_{\text {reg }}$ frequency resulting in a limited number of cells to inhibit desired immune responses, lack of stable engraftment of donor $\mathrm{T}_{\text {reg }}$ inoculums, and the need for antigen specificity of $\mathrm{T}_{\text {regs }}$.

\section{Adoptive $T_{\text {reg }}$ Therapy for Prevention of GVHD}

There has been much success in $\mathrm{T}_{\text {reg }}$ therapy to prevent GVHD [41-43], which has led to the first clinical trials with
$\mathrm{T}_{\text {reg }}$ immunotherapy in BM transplant recipients $[10,11,46]$. Since one obstacle in clinical application is low $\mathrm{T}_{\text {reg }}$ frequency, many of these clinical trials have relied upon ex vivo expanded $\mathrm{T}_{\text {regs }}$ to generate large cell numbers to be transplanted. Furthermore, experimental models demonstrated the need for a high $\mathrm{T}_{\text {reg }} / \mathrm{T}_{\text {effector }}\left(\mathrm{T}_{\text {eff }}\right)$ ratio to promote therapeutic benefit $[43,47-49]$. Several groups have pioneered in vitro $T_{\text {reg }}$ expansion protocols $[32,33][10,50-53]$ by polyclonal stimulation of autologous $\mathrm{T}_{\text {regs }}$ in the presence of high-dose IL-2. A confounding hurdle for ex vivo expansion of human $T_{\text {regs }}$ is the observation that human CD4 T cells upon activation can transiently express Foxp3 and upregulate CD25 expression. Several studies have shown natural $\mathrm{T}_{\text {regs }}$ are largely found within $\mathrm{CD} 4^{+} \mathrm{CD} 25^{+} \mathrm{CD} 127^{\text {lo }}$ population in both mice and man [54-56].

In the first clinical trial with $\mathrm{T}_{\text {reg }}$ adoptive therapy, two patients after hematopoietic stem cell transplantation (HSCT) with GVHD were given expanded $\mathrm{CD} 4^{+} \mathrm{CD} 25^{+} \mathrm{CD} 127^{\text {lo }}$ cells and showed these expanded $\mathrm{T}_{\text {regs }}$ were safe and may have therapeutic benefit [57]. In a larger phase I/II trial, Brunstein et al. utilized $\mathrm{T}_{\text {regs }}$ isolated from umbilical cord blood to lessen the possibility of expanding effector T-cell populations and found umbilical cord $\mathrm{T}_{\text {regs }}$ were safe and reduced grade I/II GVHD [10]. In another phase I/II trial, heavily conditioned hematological malignant patients following HSCT received unexpanded $\mathrm{T}_{\text {regs }}$ were found to enhance immune reconstitution, lower CMV reactivation incidence, and lower tumor relapse and GVHD [11]. This study showed immune regulation with human $\mathrm{T}_{\text {regs }}$ and safety profile in these high-risk patients. Although these GVHD trials showed great promise, in solid organ transplantation or autoimmune settings will pose more challenges due to the fact that unmanipulated recipients may not respond to $T_{\text {reg }}$ therapy as successfully because of the large presence of alloreactive or auto-reactive $T$ cells, respectively, leading to greater $T_{\text {reg }}$ numbers to achieve $T_{\text {reg }} / T_{\text {eff }}$ ratios that will favor a regulatory environment.

\section{Clinical Trials in T1D and Solid Organ Transplantation}

Because of the key role played by $\mathrm{T}_{\text {regs }}$ in self-tolerance, much effort is being devoted to developing $\mathrm{T}_{\text {reg }}$ therapy for recent onset T1D [58, 59, 60••, 61]. Clinical trials with autologous, expanded $\mathrm{T}_{\text {regs }}$ are ongoing in T1D $[60 \bullet \bullet, 61]$. At present, trials are testing unselected, polyclonal $\mathrm{T}_{\text {regs }}$, with awareness that expanded populations may include proinflammatory cells and may have limited lifespan in vivo as well as limited survival in non-lymphopenic hosts $[52,57]$. A published phase 1 study showed that in vitro expanded, autologous $\mathrm{T}_{\text {regs }}$ were safe and tolerable in children with recent onset T1D, with evidence of improved fasting C-peptide and reduced insulin 
requirement at 4 months; therapeutic effects correlated with increased $\mathrm{T}_{\text {regs }}$ post-infusion, but persisted only for a short period of time. An extended follow-up confirmed limited persistence of expanded $\mathrm{T}_{\text {regs }}$ even after a second infusion $[60 \bullet$, $61,62]$. Data emerging from these recent $T_{\text {reg }}$ trials in $T 1 D$ are indeed demonstrating limitations of current protocols that rely solely on infusion of expanded $\mathrm{T}_{\text {regs }}$ without any recipient manipulation, which strongly differs than in the clinical trials with HSCT patients.

With results in from $\mathrm{T}_{\text {reg }}$ trials in HSCT and T1D patients demonstrating that adoptive $\mathrm{T}_{\text {reg }}$ therapy is well tolerated, a trial in solid organ transplantation is now under way, the ONE study. This study is an international, multi-center phase I/II trial that will test safety and production feasibility of several regulatory cell populations, including ex vivo expanded $\mathrm{T}_{\text {regs, }}$, in living donor kidney transplant recipients. This trial aims at standardizing both experimental settings and endpoints and will likely allow collection of valuable data on the efficacy and safety of putative regulatory cell subsets for tolerance induction. In regards to $T_{\text {regs }}$, this trial will compare expanded $\mathrm{T}_{\text {regs }}$ from peripheral blood that is either polyclonal stimulated with anti-CD3 and anti-CD28 or alloantigen-driven with allogeneic antigen presenting cells (APC). Expansion protocol that utilizes stimulation with APCs, which enrich for allogeneic-specific $T_{\text {regs }}$ rather than expanding the entire $T_{\text {reg }}$ pool, could allow for a more potent $\mathrm{T}_{\text {reg }}$ population for adoptive therapy [63-66]. This type of expansion protocol is hindered by lack of sufficient time to expand recipients' $T_{\text {regs }}$ with donor APCs before transplant surgery. However, in the case of living-related kidney (or liver transplant) recipients, this approach is a more applicable strategy. Although the ONE trial is not designed to test the efficacy of the various regulatory populations, transplant patients will be immune monitored, which could provide valuable information on modulation of immune compartments following administration of regulatory cell populations and foster development of improved adoptive cell therapy for design of future clinical trials.

\section{Key Requirements for Successful Adoptive $\mathbf{T}_{\text {reg }}$ Immunotherapy}

Although the development of ex vivo expansion $\mathrm{T}_{\text {reg }}$ protocols have opened new avenues for adoptive $T_{\text {reg }}$ therapy in a clinical setting, there is still not much known about the in vivo environment necessary to support transferred donor $\mathrm{T}_{\text {regs }}$ longterm. Indeed, an often overlooked hurdle that needs to be considered for successful $\mathrm{T}_{\text {reg }}$ therapies that avoid the use of chronic immune suppression is to understand the host environment. Crucial factors required for $\mathrm{T}_{\text {reg }}$ generation, homeostasis, and function must be incorporated in design of clinical trials based on $T_{\text {reg }}$ adoptive therapy, whether these $T_{\text {regs }}$ are expanded in vitro or infused after isolation for in vivo expansion.

\section{Critical Barrier of Available Space and Minimizing Competition With Host $\mathbf{T}_{\text {regs }}$}

As described above, mutations or alterations in Foxp3 or IL-2/ IL-2R interactions lead to immune compartments devoid of $\mathrm{CD} 4{ }^{+} \mathrm{CD} 25^{+} \mathrm{T}_{\text {regs }}$ and mice die within 1-2 months from birth. Importantly, adoptive transfer of wild-type $\mathrm{T}_{\text {regs }}$ into Foxp3deficient mice prevents disease development in these models [73], and our own studies in IL-2R $\beta^{-/-}$mice showed $T_{\text {reg }}$ adoptive transfer leads to prevention of autoimmunity and tolerance to skin allografts with life-long donor $\mathrm{T}_{\text {reg }}$ engraftment and suppressor function. Unlike normal mice that have a constant production of thymic $\mathrm{T}_{\text {regs }}$, a key feature of these mice is lack of continuous competition with endogenous $T_{\text {regs }}$ because of absent thymic production and peripheral maintenance of functional $T_{\text {regs }}$ resulting in a natural space for donor $T_{\text {regs }}$ to engraft and persist. Moreover, adoptive $T_{\text {reg }}$ transfer into these mice occurred shortly after birth when the neonatal environment is initially lymphopenic followed by gradual increase in lymphocytes until homeostatic numbers are obtained as lymphocytes develop and migrate to periphery. Neonatal IL-2R $\beta^{-/-}$model demonstrates the importance of available peripheral space and lack of competition to long-term, stable donor $\mathrm{T}_{\text {reg }}$ engraftment. When a similar adoptive transfer of $\mathrm{T}_{\text {regs }}$ was performed in normal neonatal mice, there was 10fold lower donor $T_{\text {reg }}$ engraftment compared to IL-2R $\beta^{-/-}$ mice [67••], indicating that competition with endogenous $T_{\text {reg }}$ production did not allow significant donor engraftment. Several investigators have shown positive therapeutic outcomes when Ag-specific NOD $\mathrm{T}_{\text {regs }}$ were adoptively transferred into NOD mice [68, 69]. However, these experimental approaches used recipient NOD mice that were devoid of either $\mathrm{T}$ or $\mathrm{T}_{\text {reg }}$ cells, which results in natural space and lack of competition from endogenous $T_{\text {regs, }}$, which likely promoted donor $T_{\text {reg }}$ engraftment, resembling the IL-2R $\beta^{-/-}$and Foxp $3^{-/-}$models.

In experimental transplantation models, successful adoptive $T_{\text {reg }}$ therapy was achieved in likewise immunocompromised recipients, including irradiated, athymic, T-cell depleted, or $\mathrm{Rag}^{-/-}$hosts [70-74]. Although long-term donor $\mathrm{T}_{\text {reg }}$ engraftment was not examined in these studies, it is likely that the recipient lymphopenic environment promoted donor $\mathrm{T}_{\text {reg }}$ engraftment due to the reduced competition from host immune cells. For example, ablative conditioning severely depletes lymphocytes, including cells in the primary and secondary immune tissues, and lymphocyte reconstitution is exceedingly delayed, which recapitulates the in vivo environment in adoptive transfer in neonatal Foxp $3^{-/-}$and IL-2R $\beta^{-1}$ - models. Collectively, these studies indicate that for successful $\mathrm{T}_{\text {reg }}$ cell therapy, a critical obstacle that needs to be 
overcome is the competitive barrier created by the endogenous $\mathrm{T}_{\text {regs. }}$.

These observations have led to efforts in our laboratory to manipulate the $T_{\text {reg }}$ niche ("space") and minimize competition with host $T_{\text {regs }}$ in wild-type mice with the goal of improving adoptive $T_{\text {reg }}$ immunotherapy. This critical requirement was confirmed in common laboratory mouse strains in the absence of genetic manipulations, specifically in studies of BM conditioning in non-autoimmune $\mathrm{C} 57 \mathrm{BL} / 6$ and Balb/c strains [75]. Infused $\mathrm{T}_{\text {regs }}$ engrafted, persisted long term, and contributed to tolerance induction to skin allografts. However, a possible concern in these studies was that infused donor $\mathrm{T}_{\text {regs }}$ will not maintain their $\mathrm{T}_{\text {reg }}$ phenotype; it has been shown that adoptive transfer of Foxp $3{ }^{\mathrm{GFP}+} \mathrm{T}_{\text {regs }}$ into lymphopenic hosts results in a large number of cells to become GFP-negative [76-78]. However, the loss of $T_{\text {reg }}$ phenotype was dampened when $T_{\text {regs }}$ were co-injected with $\mathrm{CD} 4^{+}$GFP-negative cells and Foxp3 loss emerges in the absence of IL-2 [76]. Despite initial lymphopenia induced by our BM conditioning, donor-positive CD4 T cells maintain Foxp3 expression in both mouse strains [75]. These data together with immuno-compromised strains revealed the importance of available "space" within the $T_{\text {reg }}$ niche and minimizing competition at the time of $\mathrm{T}_{\text {reg }}$ infusion for long-term donor $\mathrm{T}_{\text {reg }}$ persistence. These studies also exemplify the success in HSCT models in both experimental rodent model and in clinical trials in the prevention of GVHD.

\section{Antigen Specificity of Adoptively Transferred $\mathbf{T}_{\text {regs }}$}

Antigen has been shown to be another key requirement for $\mathrm{T}_{\text {reg }}$ development and homeostasis. The ability of $\mathrm{T}_{\text {regs }}$ to prevent thyroiditis was lost when thyroid had been ablated, but rats retained the ability to prevent autoimmune diabetes [79], suggesting that the presence of antigen maintains a population of antigen-specific $\mathrm{T}_{\text {regs. }}$. Moreover, $\mathrm{T}_{\text {regs }}$ could be found within tolerant grafts, indicating that alloreactive $T_{\text {regs }}$ could potentially be recruited to or even retained at sites of alloantigen expression and actively participate in tolerance induction and/ or maintenance [80-83]. Other studies showed constant presence of alloantigen was required to inhibit allogeneic responses and induce tolerance to allogeneic BM cells [70, 71]. We also have shown a specific enrichment of donor $T_{\text {regs }}$ to host alloantigen following adoptive transfer of allogeneic $\mathrm{T}_{\text {regs }}$ into IL-2R $\beta^{--}$mice, indicating $\mathrm{T}_{\text {reg }}$ adoptive transfer allowed biological selection of donor inoculums resulting in therapeutic $\mathrm{T}_{\text {regs }}$ capable of regulating autoimmunity and tolerance [40]. This dominant transplantation tolerance was towards the MHC antigens that the $\mathrm{T}_{\text {regs }}$ were initially selected for. Collectively, these data have important implications in autoimmune settings. For example, in fully diabetic NOD (or T1D patients), insulin-specific or other islet-specific $\mathrm{T}_{\text {regs }}$ may not engraft due to the loss of their cognate antigens. However, antigen-specific $\mathrm{T}_{\text {regs }}$ could work in conjunction with antigen therapies, in prediabetic or recent onset diabetes where adequate $\beta$-cell mass still exists, or in islet transplant settings. Importantly, in transplant setting, allografts will act as the source of cognate antigen. Alternatively, allogeneic $T_{\text {regs }}$ from graft donors could be infused to potentially replenish these antigen-specific populations, but pose more of a challenge than recipients' antigen-specific $\mathrm{T}_{\text {regs }}$ because of their immunogenicity. These types of strategies would involve adoptive transfer of antigen-specific $T_{\text {regs }}$ using protocols that favor their long-term engraftment through in vivo antigendriven selection and expansion for improved therapeutic efficacy. Furthermore, a major benefit from utilizing antigenspecific donor $T_{\text {regs }}$ is that these $T_{\text {regs }}$ will act only where antigen is present, thereby providing a local immunotherapy.

Studies showed that $T_{\text {regs }}$ that are antigen-specific are more efficacious than polyclonal $T_{\text {regs }}$ at regulating autoimmune diabetes and responses to alloantigen [68, 83-85]. NOD mice are notoriously resistant to tolerance induction protocols [86-88]. Nonetheless, islet-specific $\mathrm{T}_{\text {regs }}$ could have positive effects on diabetes prevention and diabetes remission in recent diabetic NOD mice. Islet-specific $T_{\text {regs }}$ were isolated from BDC2.5 NOD transgenic mice and were expanded ex vivo in the presence of IL-2 and then adoptively transferred to immuno-compromised NOD mice, including $\mathrm{Rag}^{-/}$, Scid, or TCR $\alpha^{-/-}$NOD recipients together with either splenocytes from diabetic NOD mice or activated BDC 2.5 effector T cells. Diabetes prevention was achieved with very low $\mathrm{T}_{\text {reg }} / \mathrm{T}_{\text {eff }}$ ratio (1:160) and as few as 50,000-expanded BDC2.5 $\mathrm{T}_{\text {regs }}$ [69]. However, when expanded BDC2.5 $\mathrm{T}_{\text {regs }}$ were given to 13week-old wild-type NOD, diabetes was prevented with 30fold more $\mathrm{T}_{\text {regs }}\left(1.5 \times 10^{6}\right)$, while diabetes remission was achieved in only $36 \%$ of recent diabetic NOD mice with two doses of $1.5 \times 10^{6}$-expanded BDC2.5 $\mathrm{T}_{\text {regs }}$ [89]. In another study by Bluestone's group, $60 \%$ diabetes remission rates were achieved when $10^{7}$-expanded BDC2.5 $\mathrm{T}_{\text {regs }}$ were given to recent onset NOD mice [68]. These studies show that antigen-specific $T_{\text {regs }}$ were efficacious compared to expanded NOD $T_{\text {regs }}$; however, success was achieved with low $T_{\text {reg }}$ numbers only when recipient mice had available "space" and lack of competition with host $\mathrm{T}_{\text {regs }}$, indicating that similar success in autoimmune or transplant patients will require immunomodulation to recreate this in vivo environment to support their engraftment and therapeutic benefit.

In transplant setting, expansion of recipients' polyclonal $\mathrm{T}_{\text {regs }}$ with allogeneic APC leads to alloantigen-specific $T_{\text {reg }}$ enrichment allowing more potent $\mathrm{T}_{\text {reg }}$ population for immunotherapy [63-66]. Sagoo et al. developed a method based on expression of CD69 and CD71 following stimulation of $\mathrm{CD} 4^{+} \mathrm{CD} 25^{\mathrm{hi}} \mathrm{CD} 127^{\text {lo }} \mathrm{T}$ cells with allogeneic dendritic cells (DC). These activated $T_{\text {regs }}$ were readily expanded in vitro in the presence of allogeneic DC and IL-2, and in a humanized mouse model these enriched $T_{\text {regs }}$ could significantly reduce allogenic immune-mediated skin damage compared to 
polyclonal activated $\mathrm{T}_{\text {regs }}[64]$. In another study, Veerapathan et al. showed $\mathrm{CD} 4{ }^{+} \mathrm{CD} 25^{+} \mathrm{CD} 127^{\text {lo }} \mathrm{T}$ cells that were stimulated with allogeneic DC in the presence of IL-2, IL-15, and rapamycin were enriched and occurred when alloantigen was presented directly or indirectly with autologous DC pulsed with allogeneic fibroblast lysates. Either population was more potent suppressors in vitro than polyclonal expanded or non-expanded $\mathrm{T}_{\text {regs }}$ [66]. This group also demonstrated expansion of $\mathrm{T}_{\text {regs }}$ against minor major histocompatibility antigens [65]. These studies show promise that alloreactive $T_{\text {regs }}$ can be selected and expanded and are more potent than polyclonal $\mathrm{T}_{\text {regs }}$ in vitro, but failed to examine graft outcomes. Enriched allogeneic-specific $T_{\text {regs }}$ will be tested in the ONE clinical trial, and results will allow for development of improved clinical trials such that enriched donor-reactive $T_{\text {regs }}$ given after transplantation could lessen immunosuppression dosing and duration. Expanding donor-specific $\mathrm{T}_{\text {regs }}$ would be possible when living related donors are used, but expansion may be cumbersome to implement from cadaveric organ donors. If $\mathrm{T}_{\text {reg }}$ expansion protocols are shortened or if $\mathrm{T}_{\text {regs }}$ could be administered days after transplantation, these would allow sufficient time for ex vivo $T_{\text {reg }}$ expansion and could overcome this hurdle for their therapeutic application in these types of transplant patients.

\section{IL-2: Critical Factor for $T_{\text {reg }}$ Cell Development and Homeostasis}

The expression of CD25 was the initial marker used to identify a population of $\mathrm{T}_{\text {regs. }}$. Several studies, including our own, have proven that IL-2/IL-2R (IL-2 receptor) interaction represents an essential step in production and supports $\mathrm{T}_{\text {reg }}$ homeostasis in steady state [67••, 90-97] (Fig. 2). The role of IL-2 in $\mathrm{T}_{\text {reg }}$ generation and maintenance has been extensively reviewed (see $[98,99])$. Here we will focus on the role of
IL-2 in the context of $\mathrm{T}_{\text {reg }}$ therapies. If significant long-term donor $\mathrm{T}_{\text {reg }}$ engraftment will require immunomodulation prior to $\mathrm{T}_{\text {reg }}$ infusion, it may be possible that other STAT5dependent cytokines, such as IL-7 or IL-15, may act as homeostatic factor rather than IL-2 during these lymphopenic states. However, residual $\mathrm{T}_{\text {reg }}$ compartment following ablation was also highly dependent on IL-2 and IL-7 acted more as a survival factor [100]. Moreover, IL-2 was also critical for the growth and survival of infused $\mathrm{T}_{\text {regs }}$ following conditioning [75]. Despite low IL-2 in conditioned mice, levels are sufficient to drive substantial proliferation $\mathrm{T}_{\text {reg }}$ compartment. This is likely due to $T_{\text {reg }}$ homeostasis requiring low IL-2 signaling [101] and their expression of high affinity IL-2Rs over other lymphocytes allows competitive advantage for IL-2 utilization. Impaired $\mathrm{T}_{\text {reg }}$ function in NOD mice derives from low IL-2 levels in pancreas; proper IL-2 treatment restored $T_{\text {reg }}$ function and effectively reverses diabetes at onset in a fraction of mice by augmenting the $T_{\text {reg }} / T_{\text {eff }}$ ratio [102]. Furthermore, enhanced $\beta$-cell destruction occurs by Th1 and Th17 CD4 $4^{+} \mathrm{T}$ subsets in recent diabetic mice, but low-dose IL-2 administration downregulated production of these cytokines [102]. In contrast, high-dose IL-2 triggered disease likely by promoting autoreactive T cells.

IL-2 continues to be used in cancer immunotherapy at high doses to boost tumor responses, but has had limited use in autoimmune setting due to the potential risks of stimulating effector $\mathrm{T}$ cells (for review, see [13, 103]). In phase I/II pilot study combining DCs and IL-2 in metastatic renal cancer patients, a specific anti-tumor response was detected, but a transient and massive increase of circulating $\mathrm{T}_{\text {regs }}$ was also observed [104]. A phase 1 clinical trial in recent onset T1D with a combination therapy of IL-2 and rapamycin was recently completed [105]. Although there was expansion of $T_{\text {regs, }}$, there was proliferation of $\mathrm{T}_{\text {eff }}$ and $\mathrm{NK}$ cells and a worsening of metabolic function. It appears that the IL-2 dose was not

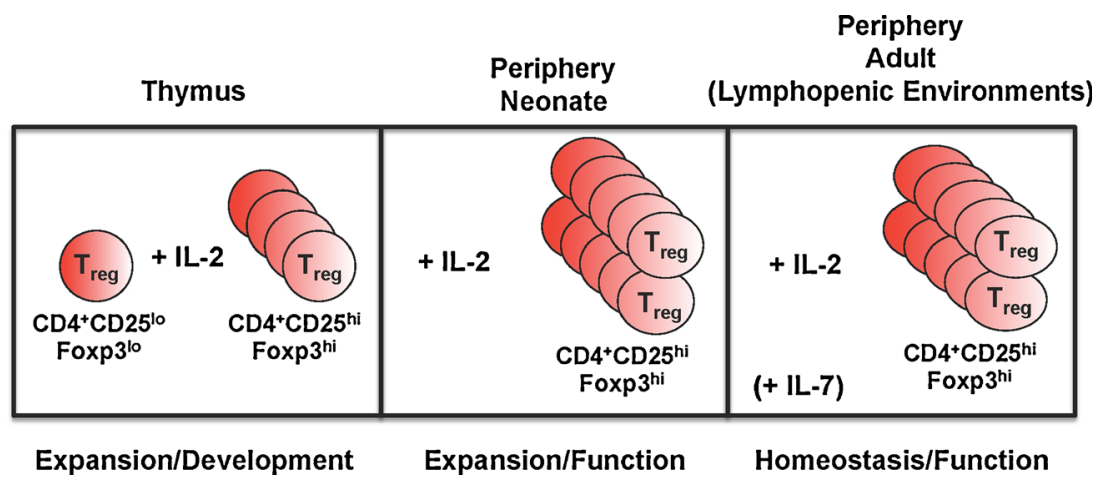

Fig. 2 Role of IL-2 for $\mathrm{T}_{\text {reg }}$ development and homeostasis. The essential role for IL-2 resides at the earliest stages of the production of $T_{\text {regs }}$ in thymus. The IL-2/IL-2R interaction is active in thymus at the earliest stage of $\mathrm{T}_{\text {reg }}$ development to promote $\mathrm{T}_{\text {reg }}$ expansion and to upregulate Foxp 3 and CD25 to normal levels. These $\mathrm{T}_{\text {regs }}$ exit the thymus and home to neonatal lymph nodes where IL-2 acts as a potent growth factor promoting substantial $\mathrm{T}_{\text {reg }}$ expansion. In the adult peripheral compartment, IL-2 remains the dominant mechanism for $\mathrm{T}_{\text {reg }}$ homeostasis, but mature $\mathrm{T}_{\text {regs }}$ can be maintained low-dose IL-2. In lymphopenic conditions, IL-2 is still the dominant cytokine controlling $\mathrm{T}_{\text {reg }}$ homeostasis and maintaining high expression of CD25 and Foxp3. IL-7 acts as a survival factor to maintain $T_{\text {regs }}$ in the periphery, whether during the steady state, lymphopenia, or following $\mathrm{T}_{\text {reg }}$ infusion following ablation 
sufficiently low to achieve only specific effects on $\mathrm{T}_{\text {regs. }}$ In an autoimmune-related $\mathrm{HCV}$-induced vasculitis clinical trial with low-dose IL-2, it showed specific $\mathrm{T}_{\text {reg }}$ activation without stimulating other $\mathrm{T}$ cells and showed a good safety profile. Importantly, low-dose IL-2 results in increased $\mathrm{T}_{\text {reg }} / \mathrm{T}_{\text {eff }}$ ratio favoring regulation, downregulates inflammation, and failed to lead to viral reactivation in these patients [106]. This group also recently reported that phase I/II study in T1D patients with low-dose IL-2 was well tolerated and IL-2 induced a dosedependent increase in proportion of $\mathrm{T}_{\text {regs }}$ [107]. These clinical trials with IL-2 have important implications in developing $\mathrm{T}_{\text {reg }}$ immunotherapy for the clinical setting in that the proper lowdose IL-2 combined with $\mathrm{T}_{\text {reg }}$ infusion following immunomodulation may allow for far fewer numbers of donor $\mathrm{T}_{\text {regs }}$ for positive therapeutic outcomes and dampen the inflammatory environment in solid organ transplantation and in autoimmunity.

\section{CD8 T Regulatory Cells: Potential Cellular Source for Adoptive $T_{\text {reg }}$ Therapy}

$\mathrm{CD} 4^{+} \mathrm{CD} 25^{+} \mathrm{Foxp}^{+}$cells have been the main cell population to date that has been tested in clinical trials. As mentioned above, the ONE trial will examine several other regulatory populations to be potentially used for therapeutic benefit. However, Harvey Cantor's group have identified an IL-15dependent, Qa-1-restricted CD8 T cell with regulatory properties that has been shown to be essential in maintenance of self-tolerance and prevention of autoimmune disease in mice [108-111]. These cells can be identified and purified on the expression of the surface markers $\mathrm{CD} 44^{+} \mathrm{CD} 122^{+} \mathrm{Ly} 49^{+}$. These cells could also be expanded ex vivo driven by peptide and infusion of these peptide-specific CD8 $\mathrm{T}_{\text {regs }}$ strongly inhibits collagen-induced arthritis mouse model by eliminating pathogenic $\mathrm{T}$ follicular helper and Th17 cells [111]. This group has recently identified the human counterpart to these murine CD8 $\mathrm{T}_{\text {regs. }}$ These human CD8 $\mathrm{T}_{\text {regs }}$ express KIR2DL2/3 or KIRDL1 along with expression of CD44 and CD122, and IL-15 promotes their activation and proliferation [112]. These cells could represent another regulatory population that could be considered in future adoptive $T_{\text {reg }}$ therapy given that these cells can be purified, expanded ex vivo, and can be antigen specific.

\section{Concluding Remarks}

Promoting immune regulation through enhancing $T_{\text {regs }}$ offers the hope to suppress many unwanted immune responses in transplantation to prevent graft rejection, as well as a plethora of autoimmune diseases and GVHD. However, results in animal models and in recent clinical trials with adoptive $T_{\text {reg }}$ therapy are highlighting the need to consider the in vivo environment to support their engraftment, persistence, and function of infused $\mathrm{T}_{\text {regs }}$ for the future design of clinic trials in solid organ transplantation. Success in both experimental models and in clinical trials required immunomodulation to recapitulate a supportive $T_{\text {reg }}$ environment. $T_{\text {reg }}$ immunotherapy in autoimmune settings will pose more challenges given chronic inflammation could create a non-supportive environment for $\mathrm{T}_{\text {regs. }}$. However, the use of low-dose IL-2 could possible overcome the inflammatory environment and foster regulation over effector responses and promote a supportive environment for stable engraftment of infused donor $\mathrm{T}_{\text {regs. }}$. The transplantation setting could provide an adequate source of cognate antigen to drive antigen-specific regulation through selection and expansion and in context of autoimmunity where self-

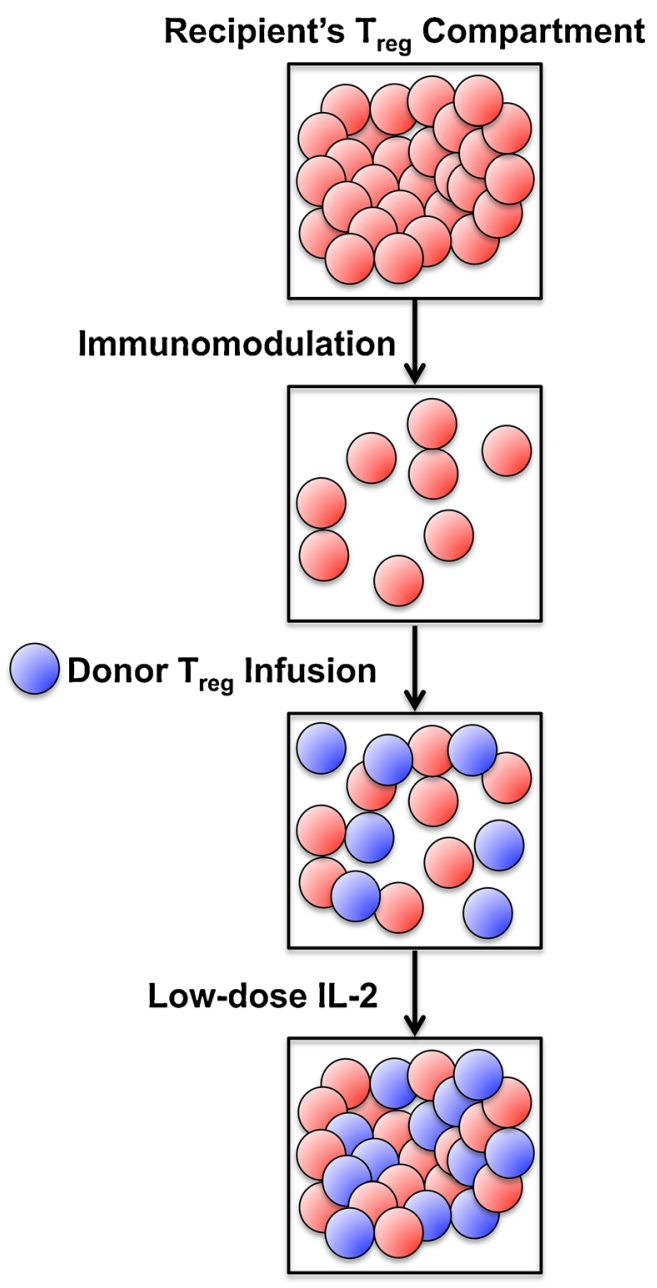

Fig. 3 In vivo environment for $\mathrm{T}_{\text {reg }}$ Immunotherapy. To recapitulate the in vivo environment to promote stable $T_{\text {reg }}$ engraftment will require immunomodulation prior to $\mathrm{T}_{\text {reg }}$ infusion. This immunomodulation needs to create initial space and minimize competition with rebounding host $T_{\text {regs }}$ to promote donor $T_{\text {regs }}$ to engraft and persist. The addition of low-dose IL-2 for homeostatic support for the Treg compartment, which will be composed of both recipient and donor $T_{\text {regs }}$, will foster $T_{\text {reg }}$ numbers, but may also play a role in stabilizing $T_{\text {reg }}$ signature and downregulate inflammation 
antigens are lost from immune destruction. Collectively, successful $\mathrm{T}_{\text {reg }}$ immunotherapy will likely require combinational approaches in which $\mathrm{T}_{\text {reg }}$ infusion occurs following immunomodulation to make space in recipient's $T_{\text {reg }}$ compartment and to minimize competition with host $\mathrm{T}_{\text {regs }}$ accompanied with low-dose IL-2 to provide homeostatic support for $\mathrm{T}_{\text {reg }}$ compartment for long-term persistence of donor $\mathrm{T}_{\text {regs }}$ (Fig. 3). However, introduction of immunomodulation could potentially have unwanted side effects that would need to be evaluated for combinational approaches. For example, the use of anti-thymoglobulin (ATG) in induction protocols leads to dramatic lymphocyte depletion and is associated with $T_{\text {reg }}$ expansion in vivo favoring a shift in $\mathrm{T}_{\text {reg }} / \mathrm{T}_{\text {eff }}$ ratio. However, CD4 and CD8 memory T cells were resistant to ATG depletion and were found to expand following treatment [113, 114]. Recently, $T_{\text {regs }}$ have been shown to play a critical role in natural killer (NK) cell homeostasis, activation, and function, predominantly by controlling the availability of IL-2 in the microenvironment [115-117]. In $\mathrm{T}_{\text {reg }}$ absence, NKs produce abundant IFN $\gamma$ and contribute to diabetic lesion in NOD mice and NKs were found to be initiators of autoimmune response by promoting CD4 $\mathrm{T}$ cells. In conclusion, future studies aimed at directly examining these issues in the context of clinically relevant approaches which could afford therapeutic synergy and considerably reduce the need for large numbers of $T_{\text {regs }}$ for therapy will provide the framework for development of novel strategies for tolerance induction.

\section{Compliance with Ethics Guidelines}

Conflict of Interest Cecilia Cabello-Kindelan, Shane Mackay, and Allison L. Bayer declare that they have no conflict of interest.

Human and Animal Rights and Informed Consent This article does not contain any studies with human or animal subjects performed by any of the authors.

\section{References}

Papers of particular interest, published recently, have been highlighted as:

- Of importance

• Of major importance

1. Fandrich F, Ungefroren H. Customized cell-based treatment options to combat autoimmunity and restore beta-cell function in type 1 diabetes mellitus: current protocols and future perspectives. Adv Exp Med Biol. 2010;654:641-65.

2. Laughlin E, Burke G, Pugliese A, Falk B, Nepom G. Recurrence of autoreactive antigen-specific $\mathrm{CD} 4^{+} \mathrm{T}$ cells in autoimmune diabetes after pancreas transplantation. Clin Immunol. 2008;128(1): 23-30.
3. Li DS, Warnock GL, Tu HJ, Ao Z, He Z, Lu H, et al. Do immunotherapy and beta cell replacement play a synergistic role in the treatment of type 1 diabetes? Life Sci. 2009;85(15-16):549-56.

4. Martins L, Malheiro J, Henriques AC, Dias L, Dores J, Oliveira F, et al. Pancreas-kidney transplantation and the evolution of pancreatic autoantibodies. Transplant Proc. 2009;41(3):913-5.

5. Meloche RM. Transplantation for the treatment of type 1 diabetes. World J Gastroenterol. 2007;13(47):6347-55.

6. Vendrame F, Pileggi A, Laughlin E, Allende G, Martin-Pagola A, Molano RD, et al. Recurrence of type 1 diabetes after simultaneous pancreas-kidney transplantation, despite immunosuppression, is associated with autoantibodies and pathogenic autoreactive CD4 T-cells. Diabetes. 2010;59(4):947-57.

7. Floess S, Freyer J, Siewert C, Baron U, Olek S, Polansky J, et al. Epigenetic control of the foxp3 locus in regulatory T cells. PLoS Biol. 2007;5(2):e38.

8. Fu S, Zhang N, Yopp AC, Chen D, Mao M, Chen D, et al. TGFbeta induces Foxp $3^{+}$T-regulatory cells from $\mathrm{CD} 4^{+} \mathrm{CD} 25^{-}$precursors. Am J Transplant Off J Am Soc Transplant Am Soc Transplant Surg. 2004;4(10):1614-27.

9. Gupta S, Shang W, Sun Z. Mechanisms regulating the development and function of natural regulatory $\mathrm{T}$ cells. Arch Immunol Ther Exp. 2008;56(2):85-102.

10. Brunstein CG, Miller JS, Cao Q, McKenna DH, Hippen KL, Curtsinger J, et al. Infusion of ex vivo expanded T regulatory cells in adults transplanted with umbilical cord blood: safety profile and detection kinetics. Blood. 2011;117(3):1061-70.

11. Di Ianni M, Falzetti F, Carotti A, Terenzi A, Castellino F, Bonifacio E, et al. Tregs prevent GVHD and promote immune reconstitution in HLA-haploidentical transplantation. Blood. 2011;117(14):3921-8.

12. Billingham RE, Brent L, Medawar PB. Quantitative studies on tissue transplantation immunity. II. The origin, strength and duration of actively and adoptively acquired immunity. Proceedings of the Royal Society of London Series B, containing papers of a Biological character Royal Society. 1954;143(910):58-80.

13. June $\mathrm{CH}$. Adoptive $\mathrm{T}$, cell therapy for cancer in the clinic. J Clin Invest. 2007;117(6):1466-76.

14. Pedrazzoli P, Comoli P, Montagna D, Demirer T, Bregni M, Ebmt S. Is adoptive T-cell therapy for solid tumors coming of age? Bone Marrow Transplant. 2012;47(8):1013-9.

15. Qin S, Cobbold SP, Pope H, Elliott J, Kioussis D, Davies J, et al. Infectious transplantation tolerance. Science. 1993;259(5097): 974-7.

16. Waldmann H, Adams E, Fairchild P, Cobbold S. Infectious tolerance and the long-term acceptance of transplanted tissue. Immunol Rev. 2006;212:301-13.

17. Dudley ME, Wunderlich JR, Robbins PF, Yang JC, Hwu P, Schwartzentruber DJ, et al. Cancer regression and autoimmunity in patients after clonal repopulation with antitumor lymphocytes. Science. 2002;298(5594):850-4.

18. Montes M, Rufer N, Appay V, Reynard S, Pittet MJ, Speiser DE, et al. Optimum in vitro expansion of human antigen-specific CD8 $\mathrm{T}$ cells for adoptive transfer therapy. Clin Exp Immunol. 2005;142(2):292-302.

19. Pilon-Thomas S, Kuhn L, Ellwanger S, Janssen W, Royster E, Marzban S, et al. Efficacy of adoptive cell transfer of tumorinfiltrating lymphocytes after lymphopenia induction for metastatic melanoma. J Immunother. 2012;35(8):615-20.

20. Rasmussen AM, Borelli G, Hoel HJ, Lislerud K, Gaudernack G, Kvalheim G, et al. Ex vivo expansion protocol for human tumor specific $\mathrm{T}$ cells for adoptive T cell therapy. J Immunol Methods. 2010;355(1-2):52-60.

21. Gershon RK, Kondo K. Cell interactions in the induction of tolerance: the role of thymic lymphocytes. Immunology. 1970;18(5): 723-37. 
22. Gershon RK, Kondo K. Degeneracy of the immune response to sheep red cells. Thymic dependency. Immunology. 1972;23(3): 335-42.

23.• Hall BM, Pearce NW, Gurley KE, Dorsch SE. Specific unresponsiveness in rats with prolonged cardiac allograft survival after treatment with cyclosporine. III. Further characterization of the $\mathrm{CD}^{+}$suppressor cell and its mechanisms of action. J Exp Med. 1990;171(1):141-57. This study was the first to demonstrate that CD4+CD25+ cells were capable of mediating transplantation tolerance in mice.

24. Sakaguchi S, Sakaguchi N, Asano M, Itoh M, Toda M. Immunologic self-tolerance maintained by activated $\mathrm{T}$ cells expressing IL-2 receptor $\alpha$-chains (CD25). Breakdown of a single mechanism of self-tolerance causes various autoimmune diseases. J Immunol. 1995;155(3):1151-64. This study demonstrated that CD4+CD25+ cells function in controlling peripheral tolerance and development of autoimmunity in mice.

25. Sakaguchi S. Naturally arising $\mathrm{CD} 4^{+}$regulatory T cells for immunologic self-tolerance and negative control of immune responses. Annu Rev Immunol. 2004;22:531-62.

26. Sakaguchi S, Sakaguchi N, Shimizu J, Yamazaki S, Sakihama T, Itoh $\mathrm{M}$, et al. Immunologic tolerance maintained by $\mathrm{CD} 25^{+} \mathrm{CD} 4^{+}$ regulatory T cells: their common role in controlling autoimmunity, tumor immunity, and transplantation tolerance. Immunol Rev. 2001;182:18-32.

27. Fontenot JD, Gavin MA, Rudensky AY. Foxp3 programs the development and function of $\mathrm{CD} 4{ }^{+} \mathrm{CD} 25^{+}$regulatory $\mathrm{T}$ cells. Nat Immunol. 2003;4(4):330-6.

28. Hori S, Nomura T, Sakaguchi S. Control of regulatory T cell development by the transcription factor Foxp3. Science. 2003;299(5609):1057-61.

29. Khattri R, Cox T, Yasayko SA, Ramsdell F. An essential role for Scurfin in $\mathrm{CD} 4{ }^{+} \mathrm{CD} 25^{+} \mathrm{T}$ regulatory cells. Nat Immunol. 2003;4(4):337-42.

30. Asano M, Toda M, Sakaguchi N, Sakaguchi S. Autoimmune disease as a consequence of developmental abnormality of a T cell subpopulation. J Exp Med. 1996;184(2):387-96.

31. Itoh M, Takahashi T, Sakaguchi N, Kuniyasu Y, Shimizu J, Otsuka $\mathrm{F}$, et al. Thymus and autoimmunity: production of $\mathrm{CD} 25^{+} \mathrm{CD} 4^{+}$ naturally anergic and suppressive T cells as a key function of the thymus in maintaining immunologic self-tolerance. J Immunol. 1999;162(9):5317-26

32. Graca L, Thompson S, Lin CY, Adams E, Cobbold SP, Waldmann H. Both CD4(+)CD25(+) and CD4(+)CD25(-) regulatory cells mediate dominant transplantation tolerance. J Immunol. 2002;168(11):5558-65.

33. Hara M, Kingsley CI, Niimi M, Read S, Turvey SE, Bushell AR, et al. IL-10 is required for regulatory T cells to mediate tolerance to alloantigens in vivo. J Immunol. 2001;166(6):3789-96.

34. Kingsley CI, Karim M, Bushell AR, Wood KJ. CD $25^{+} \mathrm{CD} 4^{+}$regulatory T cells prevent graft rejection: CTLA-4- and IL-10dependent immunoregulation of alloresponses. J Immunol. 2002;168(3):1080-6.

35. Bresson D, Togher L, Rodrigo E, Chen Y, Bluestone JA, Herold $\mathrm{KC}$, et al. Anti-CD3 and nasal proinsulin combination therapy enhances remission from recent-onset autoimmune diabetes by inducing Tregs. J Clin Invest. 2006;116(5):1371-81.

36. Graca L, Cobbold SP, Waldmann H. Identification of regulatory T cells in tolerated allografts. J Exp Med. 2002;195(12):1641-6.

37. Monti P, Scirpoli M, Maffi P, Piemonti L, Secchi A, Bonifacio E, et al. Rapamycin monotherapy in patients with type 1 diabetes modifies $\mathrm{CD}^{+} \mathrm{CD} 25^{+} \mathrm{FOXP} 3^{+}$regulatory T-cells. Diabetes. 2008;57(9):2341-7.

38. Parker MJ, Xue S, Alexander JJ, Wasserfall CH, CampbellThompson ML, Battaglia M, et al. Immune depletion with cellular mobilization imparts immunoregulation and reverses autoimmune diabetes in nonobese diabetic mice. Diabetes. 2009;58(10):227784.

39. Vergani A, D'Addio F, Jurewicz M, Petrelli A, Watanabe T, Liu K, et al. A novel clinically relevant strategy to abrogate autoimmunity and regulate alloimmunity in NOD mice. Diabetes. 2010;59(9): 2253-64.

40. Adeegbe D, Bayer AL, Levy RB, Malek TR. Cutting edge: allogeneic $\mathrm{CD} 4^{+} \mathrm{CD} 25^{+} \mathrm{Foxp}^{+}{ }^{+} \mathrm{T}$ regulatory cells suppress autoimmunity while establishing transplantation tolerance. J Immunol. 2006;176(12):7149-53.

41. Johnson BD, Konkol MC, Truitt RL. CD25+ immunoregulatory T-cells of donor origin suppress alloreactivity after BMT. Biol Blood Marrow Transplant. 2002;8(10):525-35.

42. Pilat N, Baranyi U, Klaus C, Jaeckel E, Mpofu N, Wrba F, et al. Treg-therapy allows mixed chimerism and transplantation tolerance without cytoreductive conditioning. Am J Transplan Off J Am Soc Transplant Am Soc Transplant Surg. 2010;10(4):751-62.

43. Taylor PA, Lees CJ, Blazar BR. The infusion of ex vivo activated and expanded $\mathrm{CD} 4(+) \mathrm{CD} 25(+)$ immune regulatory cells inhibits graft-versus-host disease lethality. Blood. 2002;99(10):3493-9.

44. Sakaguchi S, Ono M, Setoguchi R, Yagi H, Hori S, Fehervari Z, et al. Foxp $3^{+} \mathrm{CD} 25^{+} \mathrm{CD} 4^{+}$natural regulatory $\mathrm{T}$ cells in dominant self-tolerance and autoimmune disease. Immunol Rev. 2006;212: $8-27$.

45. Shevach EM, McHugh RS, Thornton AM, Piccirillo C, Natarajan $\mathrm{K}$, Margulies DH. Control of autoimmunity by regulatory $\mathrm{T}$ cells. Adv Exp Med Biol. 2001;490:21-32.

46. Roncarolo MG, Gregori S, Lucarelli B, Ciceri F, Bacchetta R. Clinical tolerance in allogeneic hematopoietic stem cell transplantation. Immunol Rev. 2011;241(1):145-63.

47. Hoffmann P, Boeld TJ, Piseshka B, Edinger M. Immunomodulation after allogeneic bone marrow transplantation by $\mathrm{CD} 4{ }^{+} \mathrm{CD} 25^{+}$regulatory $\mathrm{T}$ cells. Microbes Infect Institut Pasteur. 2005;7(7-8):1066-72.

48. Hoffmann P, Ermann J, Edinger M, Fathman CG, Strober S. Donor-type CD4(+)CD25(+) regulatory T cells suppress lethal acute graft-versus-host disease after allogeneic bone marrow transplantation. J Exp Med. 2002;196(3):389-99.

49. Zeng D, Lan F, Hoffmann P, Strober S. Suppression of graftversus-host disease by naturally occurring regulatory $\mathrm{T}$ cells. Transplantation. 2004;77(1 Suppl):S9-S11.

50. Earle KE, Tang Q, Zhou X, Liu W, Zhu S, Bonyhadi ML, et al. In vitro expanded human $\mathrm{CD} 4{ }^{+} \mathrm{CD} 25^{+}$regulatory T cells suppress effector T cell proliferation. Clin Immunol. 2005;115(1):3-9.

51. Hippen KL, Merkel SC, Schirm DK, Sieben CM, Sumstad D, Kadidlo DM, et al. Massive ex vivo expansion of human natural regulatory T cells (T(regs)) with minimal loss of in vivo functional activity. Sci Transl Med. 2011;3(83):83ra41.

52. Putnam AL, Brusko TM, Lee MR, Liu W, Szot GL, Ghosh T, et al. Expansion of human regulatory T-cells from patients with type 1 diabetes. Diabetes. 2009;58(3):652-62.

53. Trzonkowski P, Szarynska M, Mysliwska J, Mysliwski A. Ex vivo expansion of CD4(+)CD25(+) T regulatory cells for immunosuppressive therapy. Cytom A. 2009;75(3):175-88.

54. Liu W, Putnam AL, Xu-Yu Z, Szot GL, Lee MR, Zhu S, et al. CD127 expression inversely correlates with FoxP3 and suppressive function of human $\mathrm{CD}^{+}{ }^{+} \mathrm{T}$ reg cells. J Exp Med. 2006;203(7): 1701-11.

55. Su H, Longhi MS, Wang P, Vergani D, Ma Y. Human $\mathrm{CD} 4^{+} \mathrm{CD} 25^{\text {(high) }} \mathrm{CD} 127^{\text {(low/neg) }}$ regulatory $\mathrm{T}$ cells. Methods Mol Biol. 2012;806:287-99.

56. Yu N, Li X, Song W, Li D, Yu D, Zeng X, et al. CD4(+)CD25 (+ )CD127 (low/-) T cells: a more specific Treg population in human peripheral blood. Inflammation. 2012;35(6):1773-80.

57. Trzonkowski P, Bieniaszewska M, Juscinska J, Dobyszuk A, Krzystyniak A, Marek N, et al. First-in-man clinical results of 
the treatment of patients with graft versus host disease with human ex vivo expanded $\mathrm{CD} 4^{+} \mathrm{CD} 25^{+} \mathrm{CD} 127^{-}$T regulatory cells. Clin Immunol. 2009;133(1):22-6.

58. Juvet SC, Whatcott AG, Bushell AR, Wood KJ. Harnessing regulatory $\mathrm{T}$ cells for clinical use in transplantation: the end of the beginning. Am J Transplant. 2014;14(4):750-63.

59. Marek-Trzonkowska N, Mysliwec M, Siebert J, Trzonkowski P. Clinical application of regulatory T cells in type 1 diabetes. Pediatr Diabetes. 2013;14(5):322-32.

60.• Marek-Trzonkowska N, Mysliwiec M, Dobyszuk A, Grabowska M, Techmanska I, Juscinska J, et al. Administration of $\mathrm{CD} 4{ }^{+} \mathrm{CD} 25^{\text {high }} \mathrm{CD} 127^{-}$regulatory $\mathrm{T}$ cells preserves beta-cell function in type 1 diabetes in children. Diabetes Care. 2012;35(9):1817-20. This trial provided evidence for using ex vivo expanded $T$ regulatory cells for the treatment of type 1 diabetes.

61. Trzonkowski P. Repetitive administration of $\mathrm{CD} 4{ }^{+} \mathrm{CD} 25^{\text {high }} \mathrm{CD} 127^{-} \mathrm{T}$ regulatory cells prolongs survival of pancreatic islets in type 1 diabetes in children. Chicago: 2013 ADA Annual Meeting; 2013.

62. Marek-Trzonkowska N, Mysliwiec M, Dobyszuk A, Grabowska M, Derkowska I, Juscinska J, et al. Therapy of type 1 diabetes with $\mathrm{CD} 4{ }^{+} \mathrm{CD} 25^{\text {high }} \mathrm{CD} 127^{-}$regulatory $\mathrm{T}$ cells prolongs survival of pancreatic islets - results of one year follow-up. Clin Immunol. 2014;153(1):23-30.

63. Putnam AL, Safinia N, Medvec A, Laszkowska M, Wray M, Mintz MA, et al. Clinical grade manufacturing of human alloantigen-reactive regulatory $\mathrm{T}$ cells for use in transplantation. Am J Transplan Off J Am Soc Transplant Am Soc Transplant Surg. 2013;13(11):3010-20.

64. Sagoo P, Ali N, Garg G, Nestle FO, Lechler RI, Lombardi G. Human regulatory $\mathrm{T}$ cells with alloantigen specificity are more potent inhibitors of alloimmune skin graft damage than polyclonal regulatory T cells. Sci Transl Med. 2011;3(83):83ra42.

65. Veerapathran A, Pidala J, Beato F, Betts B, Kim J, Turner JG, et al. Human regulatory $\mathrm{T}$ cells against minor histocompatibility antigens: ex vivo expansion for prevention of graft-versus-host disease. Blood. 2013;122(13):2251-61.

66. Veerapathran A, Pidala J, Beato F, Yu XZ, Anasetti C. Ex vivo expansion of human Tregs specific for alloantigens presented directly or indirectly. Blood. 2011;118(20):5671-80.

67.• Malek TR, Yu A, Vincek V, Scibelli P, Kong L. CD4 regulatory T cells prevent lethal autoimmunity in IL-2R $\beta$-deficient mice. Implications for the nonredundant function of IL-2. Immunity. 2002;17(2):167-78. This study demonstrated the main non-redundant role of IL-2 is in the production of $\mathrm{T}$ regulatory cells.

68. Tang Q, Henriksen KJ, Bi M, Finger EB, Szot G, Ye J, et al. In vitro-expanded antigen-specific regulatory $\mathrm{T}$ cells suppress autoimmune diabetes. J Exp Med. 2004;199(11):1455-65.

69. Tarbell KV, Yamazaki S, Olson K, Toy P, Steinman RM. CD25 $\mathrm{CD}^{+} \mathrm{T}$ cells, expanded with dendritic cells presenting a single autoantigenic peptide, suppress autoimmune diabetes. J Exp Med. 2004;199(11):1467-77.

70. Joffre O, Gorsse N, Romagnoli P, Hudrisier D, van Meerwijk JP. Induction of antigen-specific tolerance to bone marrow allografts with $\mathrm{CD} 4^{+} \mathrm{CD} 25^{+}$T lymphocytes. Blood. 2004;103(11):4216-21.

71. Joffre O, Santolaria T, Calise D, Al Saati T, Hudrisier D, Romagnoli $\mathrm{P}$, et al. Prevention of acute and chronic allograft rejection with $\mathrm{CD}^{+} \mathrm{CD} 25^{+} \mathrm{Foxp}^{+}$regulatory T lymphocytes. Nat Med. 2008;14(1):88-92.

72. Tsang JY, Tanriver Y, Jiang S, Leung E, Ratnasothy K, Lombardi $\mathrm{G}$, et al. Indefinite mouse heart allograft survival in recipient treated with $\mathrm{CD} 4(+) \mathrm{CD} 25(+)$ regulatory $\mathrm{T}$ cells with indirect allospecificity and short term immunosuppression. Transpl Immunol. 2009;21(4):203-9.
73. Velasquez-Lopera MM, Eaton VL, Lerret NM, Correa LA, Decresce RP, Garcia LF, et al. Induction of transplantation tolerance by allogeneic donor-derived CD4(+)CD25(+)Foxp3(+) regulatory T cells. Transpl Immunol. 2008;19(2):127-35.

74. Xia G, He J, Zhang Z, Leventhal JR. Targeting acute allograft rejection by immunotherapy with ex vivo-expanded natural $\mathrm{CD}^{+} \mathrm{CD}^{2} 5^{+}$regulatory T cells. Transplantation. 2006;82(12): $1749-55$

75. Cabello-Kindelan C, de la Barrera A, Malek TR, Bayer AL. In vivo environment necessary to support transplanted donor mouse $\mathrm{T}$ regulatory cells. Am J Transplant Off J Am Soc Transplant Am Soc Transplant Surg. 2014;14(5):1032-45.

76. Duarte JH, Zelenay S, Bergman ML, Martins AC, Demengeot J. Natural Treg cells spontaneously differentiate into pathogenic helper cells in lymphopenic conditions. Eur J Immunol. 2009;39(4):948-55.

77. Komatsu N, Mariotti-Ferrandiz ME, Wang Y, Malissen B, Waldmann H, Hori S. Heterogeneity of natural Foxp $3^{+}$T cells: a committed regulatory T-cell lineage and an uncommitted minor population retaining plasticity. Proc Natl Acad Sci U S A. 2009;106(6):1903-8.

78. Yurchenko E, Shio MT, Huang TC, Da Silva MM, Szyf M, Levings MK, et al. Inflammation-driven reprogramming of $\mathrm{CD}^{+}{ }^{+}$Foxp $^{+}$regulatory T cells into pathogenic Th1/Th17 T effectors is abrogated by mTOR inhibition in vivo. PLoS One. 2012;7(4):e35572.

79. Seddon B, Mason D. Peripheral autoantigen induces regulatory T cells that prevent autoimmunity. J Exp Med. 1999;189(5):877-82.

80. Apostolou I, Sarukhan A, Klein L, von Boehmer H. Origin of regulatory $\mathrm{T}$ cells with known specificity for antigen. Nat Immunol. 2002;3(8):756-63.

81. Cozzo C, Larkin 3rd J, Caton AJ. Cutting edge: self-peptides drive the peripheral expansion of $\mathrm{CD} 4{ }^{+} \mathrm{CD} 25^{+}$regulatory $\mathrm{T}$ cells. $\mathrm{J}$ Immunol. 2003;171(11):5678-82.

82. Salomon B, Lenschow DJ, Rhee L, Ashourian N, Singh B, Sharpe A, et al. B7/CD28 costimulation is essential for the homeostasis of the $\mathrm{CD} 4^{+} \mathrm{CD} 25^{+}$immunoregulatory $\mathrm{T}$ cells that control autoimmune diabetes. Immunity. 2000;12(4):431-40.

83. Tang Q, Henriksen KJ, Boden EK, Tooley AJ, Ye J, Subudhi SK, et al. Cutting edge: CD28 controls peripheral homeostasis of $\mathrm{CD}^{+} \mathrm{CD} 25^{+}$regulatory T cells. J Immunol. 2003;171(7):334852.

84. Yamazaki S, Inaba K, Tarbell KV, Steinman RM. Dendritic cells expand antigen-specific Foxp $3^{+} \mathrm{CD} 25^{+} \mathrm{CD} 4^{+}$regulatory T cells including suppressors of alloreactivity. Immunol Rev. 2006;212: 314-29.

85. Yamazaki S, Iyoda T, Tarbell K, Olson K, Velinzon K, Inaba K, et al. Direct expansion of functional $\mathrm{CD} 25^{+} \mathrm{CD} 4^{+}$regulatory $\mathrm{T}$ cells by antigen-processing dendritic cells. J Exp Med. 2003;198(2):235-47.

86. Markees TG, Serreze DV, Phillips NE, Sorli CH, Gordon EJ, Shultz LD, et al. NOD mice have a generalized defect in their response to transplantation tolerance induction. Diabetes. 1999;48(5):967-74.

87. Pearson T, Markees TG, Serreze DV, Pierce MA, Marron MP, Wicker LS, et al. Genetic disassociation of autoimmunity and resistance to costimulation blockade-induced transplantation tolerance in nonobese diabetic mice. J Immunol. 2003;171(1):18595.

88. Pearson T, Markees TG, Wicker LS, Serreze DV, Peterson LB, Mordes JP, et al. NOD congenic mice genetically protected from autoimmune diabetes remain resistant to transplantation tolerance induction. Diabetes. 2003;52(2):321-6.

89. Tarbell KV, Petit L, Zuo X, Toy P, Luo X, Mqadmi A, et al Dendritic cell-expanded, islet-specific $\mathrm{CD} 4{ }^{+} \mathrm{CD} 25^{+} \mathrm{CD} 62 \mathrm{~L}^{+}$ 
regulatory T cells restore normoglycemia in diabetic NOD mice. $\mathrm{J}$ Exp Med. 2007;204(1):191-201.

90. Almeida AR, Legrand N, Papiernik M, Freitas AA. Homeostasis of peripheral $\mathrm{CD} 4^{+} \mathrm{T}$ cells: IL-2R $\alpha$ and IL-2 shape a population of regulatory cells that controls $\mathrm{CD} 4^{+} \mathrm{T}$ cell numbers. J Immunol. 2002;169(9):4850-60.

91. Bayer AL, Yu A, Adeegbe D, Malek TR. Essential role for interleukin-2 for $\mathrm{CD} 4{ }^{+} \mathrm{CD} 25^{+}$T regulatory cell development during the neonatal period. J Exp Med. 2005;201(5):769-77.

92. Bayer AL, Yu A, Malek TR. Function of the IL-2R for thymic and peripheral $\mathrm{CD} 4{ }^{+} \mathrm{CD} 25^{+}$Foxp $^{+} \mathrm{T}$ regulatory cells. J Immunol. 2007;178(7):4062-71.

93. D'Cruz LM, Klein L. Development and function of agonistinduced $\mathrm{CD} 25^{+} \mathrm{Foxp}^{+}{ }^{+}$regulatory $\mathrm{T}$ cells in the absence of interleukin 2 signaling. Nat Immunol. 2005;6(11):1152-9.

94. Fontenot JD, Rasmussen JP, Gavin MA, Rudensky AY. A function for interleukin 2 in Foxp3-expressing regulatory $T$ cells. Nat Immunol. 2005;6(11):1142-51.

95. Furtado GC, de Lafaille MA C, Kutchukhidze N, Lafaille JJ. Interleukin 2 signaling is required for $\mathrm{CD}^{+}$regulatory $\mathrm{T}$ cell function. J Exp Med. 2002;196(6):851-7.

96. Setoguchi R, Hori S, Takahashi T, Sakaguchi S. Homeostatic maintenance of natural Foxp $3^{+} \mathrm{CD} 25^{+} \mathrm{CD} 4^{+}$regulatory $\mathrm{T}$ cells by interleukin (IL)-2 and induction of autoimmune disease by IL-2 neutralization. J Exp Med. 2005;201(5):723-35.

97. Wolf M, Schimpl A, Hunig T. Control of T cell hyperactivation in IL-2-deficient mice by $\mathrm{CD} 4^{+} \mathrm{CD} 25^{-}$and $\mathrm{CD} 4^{+} \mathrm{CD} 25^{+} \mathrm{T}$ cells: evidence for two distinct regulatory mechanisms. Eur $\mathrm{J}$ Immunol. 2001;31(6):1637-45.

98. Bayer AL, Pugliese A, Malek TR. The IL-2/IL-2R system: from basic science to therapeutic applications to enhance immune regulation. Immunol Res. 2013;57(1-3):197-209.

99. Malek TR, Bayer AL. Tolerance, not immunity, crucially depends on IL-2. Nat Rev Immunol. 2004;4(9):665-74.

100. Bayer AL, Chirinos J, Cabello C, Yang J, Matsutani T, Malek TR, et al. Expansion of a restricted residual host T reg-cell repertoire is dependent on IL-2 following experimental autologous hematopoietic stem transplantation. Eur J Immunol. 2011;41(12):3467-78.

101. Yu A, Zhu L, Altman NH, Malek TR. A low interleukin-2 receptor signaling threshold supports the development and homeostasis of T regulatory cells. Immunity. 2009;30(2):204-17.

102. Grinberg-Bleyer Y, Baeyens A, You S, Elhage R, Fourcade G, Gregoire S, et al. IL-2 reverses established type 1 diabetes in NOD mice by a local effect on pancreatic regulatory T cells. $\mathrm{J}$ Exp Med. 2010;207(9):1871-8.

103. Rosenzwajg M, Churlaud G, Hartemann A, Klatzmann D. Interleukin 2 in the pathogenesis and therapy of type 1 diabetes. Curr Diabetes Rep. 2014;14(12):553.

104. Lemoine FM, Cherai M, Giverne C, Dimitri D, Rosenzwajg M, Trebeden-Negre H, et al. Massive expansion of regulatory T-cells following interleukin 2 treatment during a phase I-II dendritic cell-based immunotherapy of metastatic renal cancer. Int $\mathbf{J}$ Oncol. 2009;35(3):569-81.

105. Long AS, Rieck M, Sanda S, Bollyky JB, Samuels PL, Goland R, et al. Rapamycin/IL-2 combination therapy in patients with type 1 diabetes augments Tregs yet transiently impairs $\beta$-cell function. Diabetes. 2012. doi:10.2337/db12-0049. Published online before print June 20, 2012.

106. Saadoun D, Rosenzwajg M, Joly F, Six A, Carrat F, Thibault V, et al. Regulatory T-cell responses to low-dose interleukin-2 in HCV-induced vasculitis. N Engl J Med. 2011;365(22):2067-77.

107. Hartemann A, Bensimon G, Payan CA, Jacqueminet S, Bourron $\mathrm{O}$, Nicolas $\mathrm{N}$, et al. Low-dose interleukin 2 in patients with type 1 diabetes: a phase $1 / 2$ randomised, double-blind, placebocontrolled trial. Lancet Diabetes Endocrinol. 2013;1(4):295-305.

108. Kim HJ, Cantor H. Regulation of self-tolerance by Qa-1-restricted CD8(+) regulatory T cells. Semin Immunol. 2011;23(6):446-52.

109. Kim HJ, Verbinnen B, Tang X, Lu L, Cantor H. Inhibition of follicular T-helper cells by $\mathrm{CD} 8(+)$ regulatory T cells is essential for self tolerance. Nature. 2010;467(7313):328-32.

110. Kim HJ, Wang X, Radfar S, Sproule TJ, Roopenian DC, Cantor H. $\mathrm{CD}^{+}{ }^{+}$T regulatory cells express the Ly49 Class I MHC receptor and are defective in autoimmune prone B6-Yaa mice. Proc Natl Acad Sci U S A. 2011;108(5):2010-5.

111. Leavenworth JW, Tang X, Kim HJ, Wang X, Cantor H. Amelioration of arthritis through mobilization of peptidespecific $\mathrm{CD}^{+}$regulatory T cells. J Clin Invest. 2013;123(3): 1382-9.

112. Holderried TA, Kim HJ, Lang PA, Cantor H. $\mathrm{CD}^{+}$Treg-from mouse to man. Blood. 2013;122(21):3474.

113. Gitelman SE, Gottlieb PA, Rigby MR, Felner EI, Willi SM, Fisher LK, et al. Antithymocyte globulin treatment for patients with recent-onset type 1 diabetes: 12 months results of a randomised, placebo-controlled, phase 2 trial. Lancet Diabetes Endocrinol. 2013;1(4):306-16.

114. Gurkan S, Luan Y, Dhillon N, Allam SR, Montague T, Bromberg JS, et al. Immune reconstitution following rabbit antithymocyte globulin. Am J Transplant Off J Am Soc Transplant Am Soc Transplant Surg. 2010;10(9):2132-41.

115. Feuerer M, Shen Y, Littman DR, Benoist C, Mathis D. How punctual ablation of regulatory $\mathrm{T}$ cells unleashes an autoimmune lesion within the pancreatic islets. Immunity. 2009;31(4):654-64.

116. Gasteiger G, Hemmers S, Firth MA, Le Floc'h A, Huse M, Sun JC, et al. IL-2-dependent tuning of NK cell sensitivity for target cells is controlled by regulatory T cells. J Exp Med. 2013;210(6): 1167-78.

117. Sitrin J, Ring A, Garcia KC, Benoist C, Mathis D. Regulatory T cells control NK cells in an insulitic lesion by depriving them of IL-2. J Exp Med. 2013;210(6):1153-65. 